\title{
The Effect of Using Web-Based Interactive Learning Media for Vocational High School Students to Understanding of Looping: Qualitative Approach
}

\author{
Dwi Fitria Al Husaeni ${ }^{*}$, Enrico Nabil Qois Budisantosoํㅜ, Mushfani Ainul Urwah ${ }^{1}$, Nissa Nur \\ Azizah ${ }^{1}$, Putri Zukhruf Dinata ${ }^{1}$, Shandini Apriliany ${ }^{1}$, Herbert Siregar ${ }^{1}$
}

${ }^{1}$ Department of Computer Science Education, Faculty of Mathematics and Science Education, Universitas Pendidikan Indonesia, Bandung, Indonesia

*Corresponding Author dwifitriaalhusaeni@upi.edu

\begin{abstract}
This study aims to evaluate the effect of the use and development of interactive and visual learning media in learning looping by utilizing a web-based digital platform called Loopers. The research design used a qualitative descriptive with case study approach in-depth interview technique. The subjects of this research are five students of the State Vocational School Pekerjaan Umum, Bandung, Indonesia. We use three phases in conducting research through 1) problem and needs analysis, 2) web design, and 3) implementation and testing. Loopers were developed using the waterfall method. Loopers can demonstrate the implementation of a productive learning process and measure the effectiveness of interactive and visualized learning media. The findings show that Loopers can effectively facilitate experimental demonstrations and written modules. Respondents think this learning media is effective and can increase their interest, motivation, and interest in learning looping material. The next research is to enrich the Loopers feature and conduct trials with larger respondents.
\end{abstract}

Keywords Looping, Basic Programming, Experimental Demonstration, Vocational School, Website

\section{INTRODUCTION}

Looping is a method of repeating a procedure as many times as predetermined stopping conditions allow (Shouthiri \& Thushika, 2018). Since many software applications repeat their work until the desired condition is reached, looping is an essential part of programming (Grover, Jackiw, \& Lundh, 2019). With iterations, programmers are not required to write as much program code as they would like (Brown \& Wilson, 2018).

Looping is one of the material scopes that must be studied in basic programming subjects at the basic competency (known as KD) 3.7 and 4.7 levels of vocational school education, namely applying a loop control structure in programming languages and creating program code for a loop control structure. The material taught is looping with initial, final, user-inputted conditions, continue, and a break statement. However, when it comes to learning the loop concept, vocational school students find the material difficult. This is evidenced by the results of a survey of 23 vocational students conducted by the author using Google Forms, in which $45.5 \%$ responded that there were subjects that were difficult to understand, namely basic programming subjects on looping material. This is consistent with Esteves, Fonseca, Morgado, \& Martins (2011), who state that a programming language has a broad and complex syntax (Attallah, 2017). Learning programming languages will undoubtedly be difficult for inexperienced students. Programming languages are one of the subjects that require a high level of qualification (Çoklar \& Akçay, 2018). As a result of the high qualifications possessed by this subject, many students are required to repeat and even drop out of school. Respondents' reasons for difficult-to-understand material include (1) a lack of creative learning media, (2) unclear explanations of material, (3) a lack of material sources/references, (4) a lack of examples of application provided, and (5) inadequate learning facilities.

It is critical to assist students in understanding loops. One method for learning loops more easily is visualizing and creating a learning media. Presentation of material is more visual; for example, videos can help students learn more effectively (Afriani \& Agustin, 2019; Cetin, 2020). Vocational schools continue to use learning media in

Received: 24 June 2021

Revised: 3 October 2021

Published: 1 March 2022 
printed books, digital e-books, tutorial articles on websites, and video tutorials for learning programming languages.

Many studies on looping material have been conducted, including research related to the expression of the term looping in semantic programming (Goncharov, Ospichev, Ponomaryov, \& Sviridenko, 2019), research conducted by Shouthiri and Thushika (2018) regarding comparative analysis of the looping structure by comparing the loop structure of the While Loop and Do-While Loop in C++ language (Shouthiri \& Thushika, 2018), making looping a formal concept (Manik, 2020), research on combining active learning with inductive logic programming to close the loop in machine learning (Bryant, Muggleton, Page, \& Sternberg, 1999) and teaching various kinds of loops for beginners with program examples (Tam, 1992). However, no research has been conducted on web-based learning media in terms of looping material that is explicitly presented and in detail with a higher and more dominant level of complexity in presenting the material and the interaction between the system and students through the incorporation of descriptive, visual, audio-video, and other media. Quizzes on media and other practice questions.

As a result, this study was carried out to aid in the efficient facilitation of the learning process. The preliminary research findings to ascertain vocational school students' opinions on learning media development revealed that students agreed with digital learning assistance in learning. Increasing student learning time with digital learning, in particular, increases learning achievement relatively (Lin \& Chen, 2017). The digital platform's innovation is to combine various learning media on one platform, making it easier for students to access loop material, such as learning videos, learning modules, and quizzes/games that are free, open-source, and user friendly.

This study aims to test the effect of using and developing more interactive and visual learning media on understanding looping material through experimental demonstrations using a web-based digital platform for vocational students. Analysis of student learning outcomes and understanding and the effectiveness of learning media is carried out by interviewing students and reviewing the results of the quizzes provided on the created website. This research is expected to help students understand basic programming concepts, particularly looping, so that students can meet KD 3.7 and 4.7 .

\section{METHOD}

\subsection{Research Subject}

Respondents in this study included five students from the vocational school Computer and Network Engineering expertise program, two in grade 10 and three in grade 11. We assigned R1, R2, R3, R4, and R5 to five respondents. Respondents comprised 40\% male students and 60\% female students, with a median age of 16 years and a maximum age of 17 years.

\subsection{Design Analysis}

The qualitative descriptive method with the case study approach was used in this study. In addition, the researchers used an in-depth interview technique. The waterfall method is used in the creation of learning media. The waterfall is carried out systematically, beginning with the system requirements design stage and progressing to the analysis stage, web design, web testing, and maintenance. Figure 1 depicts the research's three phases: Problem and needs analysis, web design, and implementation and testing.

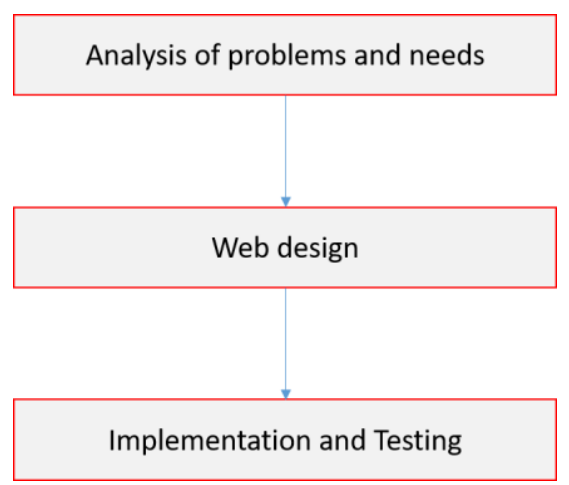

Figure 1 Research stages

\subsection{Analysis of the Problem and Needs}

In the Problem and Needs Analysis step, we identified the inputs and outputs and the media used to develop Loopers. An open questionnaire distributed via Google forms to 23 vocational school students with expertise in Computer and Informatics Engineering in Bandung,

Table 1 Question for analysis of the problem and needs

\begin{tabular}{|c|c|}
\hline Number & Question \\
\hline 1 & In your opinion, are there subjects that are difficult to understand? \\
\hline 2 & What subjects do you find difficult to understand? \\
\hline 3 & $\begin{array}{l}\text { From these subjects, what material do you think is the most difficult to understand (Can write one or more } \\
\text { chapters of material)? }\end{array}$ \\
\hline 4 & $\begin{array}{l}\text { In your opinion, what causes the material to be challenging to understand? (explain whether there is a lack } \\
\text { of sources or references, whether the teacher does not explain in detail, the learning media lacks, etc.). }\end{array}$ \\
\hline 5 & $\begin{array}{l}\text { Choose the learning media that you want to make it easier to understand the material (Can be more than one } \\
\text { choice) }\end{array}$ \\
\hline
\end{tabular}




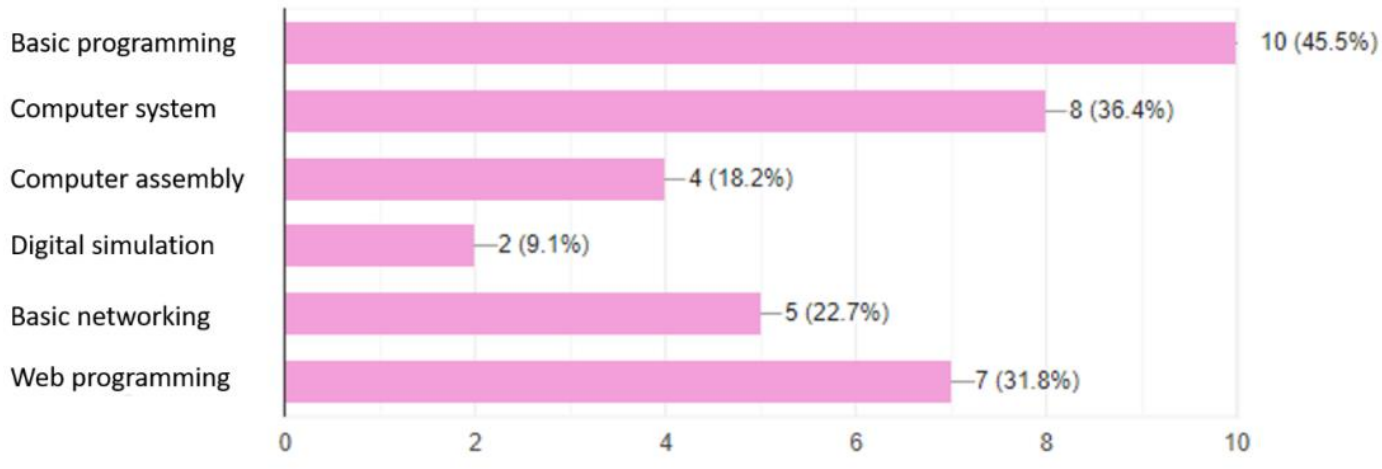

Figure 2 Subjects that are difficult for students to understand

Indonesia, was used to analyze problems and needs. We asked respondents five questions in Table 1 about difficultto-understand skill subjects and preferred learning media to help students understand the material.

Figure 2 shows that $45.5 \%$ of the 23 students responded to difficult-to-understand subjects, namely basic programming subjects on looping material.

The questionnaire answers are used to identify subjects, sub-materials, and media that will be utilized to create Loopers web-based learning media.

\subsection{Web Design}

The analysis results are implemented using a programming language during the design stage. Several diagram design media are used in the design process (such as Data Flow Diagram (DFD), Flowchart, Entity Relationship Diagram (ERD), and Sitemap). In addition, we design learning media that will be used on the website Loopers creation system based on the problem results and need analysis. Learning videos, Portable Document Format (PDF) materials, quizzes, enrichment questions, and a top score system are among the media used.

Table 2 Question of interview process

\begin{tabular}{|c|c|}
\hline Number & Question \\
\hline \multirow[t]{3}{*}{1} & Have you studied repetition in school? \\
\hline & If so, did you have difficulty in learning it? Please explain the difficulties experienced if yes. \\
\hline & If not, do you have an interest in learning basic programming, especially looping material? \\
\hline \multirow[t]{3}{*}{2} & Previously, have you ever tried using learning media like Loopers? \\
\hline & If yes, state the website's name and how you feel or the difference between the two websites. \\
\hline & If not, what do you think about making learning media like Loopers? \\
\hline 3 & What do you think about the appearance of web Loopers (first impressions)? \\
\hline 4 & What do you think when operating this website? Are you having trouble accessing some of the features on this website? \\
\hline 5 & How far have you learned the material? Has everything been done? \\
\hline 6 & Is the material displayed on the web in accordance with the learning material described in class? \\
\hline 7 & $\begin{array}{l}\text { Has the Looper website helped you understand basic programming subjects, especially Looping material? State the } \\
\text { reason. }\end{array}$ \\
\hline \multirow[t]{2}{*}{8} & Are there any difficulties in understanding the looping material on this web? \\
\hline & If so, what materials are still difficult to understand in this web learning media? \\
\hline 9 & $\begin{array}{l}\text { There are teaching materials in modules, videos, and quizzes on the web. Do you think the teaching materials are } \\
\text { sufficient to understand your knowledge of repetition? }\end{array}$ \\
\hline 10 & Does visualizing more (Video) the material makes you more interested in learning a material? Explain why. \\
\hline 11 & How is the learning video shown? Is it interesting to watch? If so, why? If not, why? \\
\hline 12 & Have you filled out the quiz? If so, what were the results? And give your opinion on the quiz as a whole. \\
\hline 13 & What do you think about providing learning media such as this Looper website? \\
\hline 14 & What do you think about web Loopers? Who is interested in learning or not? If so, why? If not, why? \\
\hline 15 & Can the existence of learning media such as this Looper increase your motivation in learning? State the reason. \\
\hline 16 & $\begin{array}{l}\text { In your opinion, is this web-based learning media effective, efficient, and useful for people who have difficulty } \\
\text { understanding repetition? Explain. }\end{array}$ \\
\hline 17 & Mention what you like on this website. \\
\hline 18 & Can friends tell us about the advantages and disadvantages after trying the Loopers learning web? \\
\hline 19 & Would you recommend this website to your friends? \\
\hline 20 & State your hopes for this website in the future. \\
\hline
\end{tabular}


The use of video in learning is more appealing to students. Learning videos help students understand looping material through audio-visual means, making the material delivered more interactive and visual. Meanwhile, the material module in PDF format is presented for students who prefer to read. Furthermore, the PDF module includes a function that allows students to review material on the Loopers web without playing videos. Before taking the school exam, students can easily review the looping material.

The quiz function is a collection of practice questions that students can complete after studying the offered information. This quiz allows students to assess themselves after completing the learning process. In addition, the Loopers system now includes a scoring system and a feature for determining the highest score to increase students' motivation to learn. Furthermore, the scoring tool enables students to see their abilities and progress in studying.

\subsection{Implementation and Testing}

We began designing the system using a programming language throughout the implementation stage. PHP: Hypertext Preprocessor (PHP) and MySQL are utilized to create Loopers learning media accessible via a website. PHP is used to create client-side web pages. MySQL is a database management system that is utilized on the serverside. The Loopers website will then be tested.

Nine students from the Indonesia University of Education participated in the testing stage. Six women and three men served as examiners. The test is conducted in three stages: 1) The examiner runs the Loopers web, 2) the examiner tries all of the Loopers web's features, and 3) the examiner provides criticism, suggestions, and input. Figure 3 shows the stages of testing.

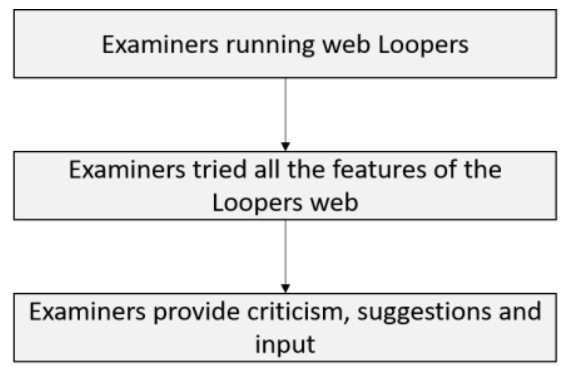

Figure 3 Stages of testing web Loopers

\subsection{Teaching Method}

The teaching method employed is experimental demonstration development media via a web-based digital platform. The research was carried out in stages, the first of which was the distribution of learning media to students. Following that, interviews were conducted in which students were asked 20 open-ended questions shown in Table 2. Before beginning the learning and interview process, information about the importance of basic programming subjects is gathered to determine the students' starting abilities.

\section{RESULTS AND DISCUSSION}

The web Loopers are divided into six sections: home, about, class, login, material, and contact. The feature has a hierarchy that can be linked to other features. The home feature, which can access logins, classes, about, materials, and contracts, becomes the center of the hierarchy. Class features provide access to the material. Login feature for accessing home, sign up, and class. Logins, classes, materials, and quizzes can all be accessed via material features.

Loopers learning media is an open-source learning media because it does not require students to register first. On the Loopers web, students can freely access all features except the quiz feature. It is intended that students find it simple to carry out learning activities.

Students who access the Loopers site will be provided a Loopers learning module that includes two forms of media, video and PDF. In addition, students can assess their learning by taking quizzes available on the Loopers website. The system will respond to students by displaying the quiz scores they have completed. In addition, the Loopers web system will provide students with answer keys and corrections for filling out quizzes. The answer key function allows students to discover what mistakes they made when filling out the quiz, allowing them to learn again and impacting student learning outcomes (Sa'adah, Nurkamto, \& Suparno, 2018).

\subsection{Features of Web Loopers Learning Media}

\section{Class Features}

Figure 4 shows a class page with a list of looping materials for students to follow. Students can choose from 14 classes, which include the introduction of basic looping, increment $(++)$ and decrement (--) operators, mathematical expressions in looping, counters, for statements, nested for statements, while statements, nested while statements, do-while statements, infinity statements, break statements, continue statements, and go-to statements.

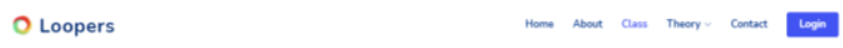

Class

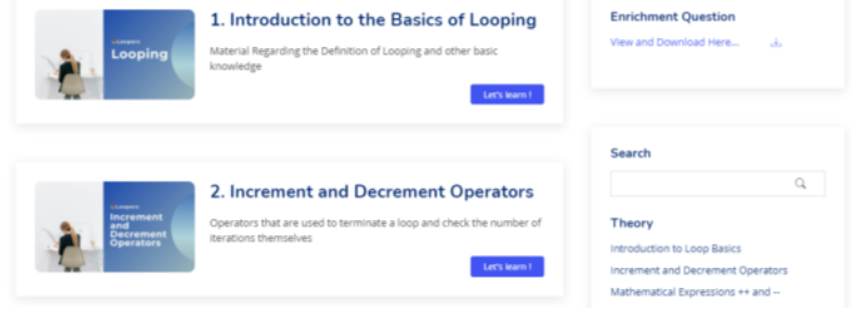

Figure 4 Class page 


\section{Definition of loop}

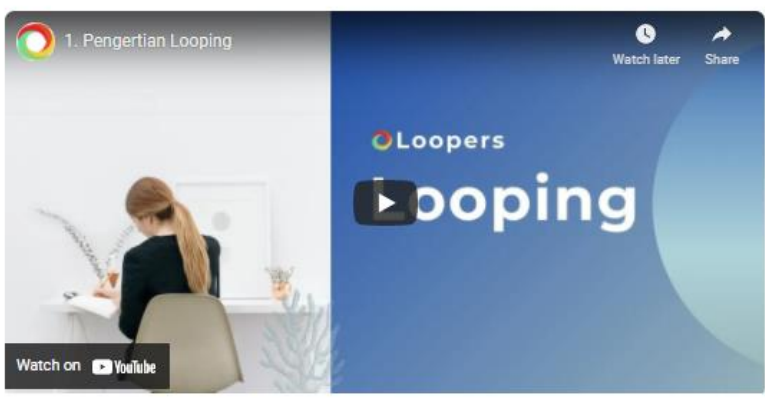

\& Shandini Apriliany (1) 2021-06-04 09:35:47

Anyone know what looping is? Well, in this chapter we will learn about the basic concept of looping. So before we learn about other looping material, let's understand the concept of looping from this video first.

Take Quiz

Figure 5 Presentation on the web Loopers

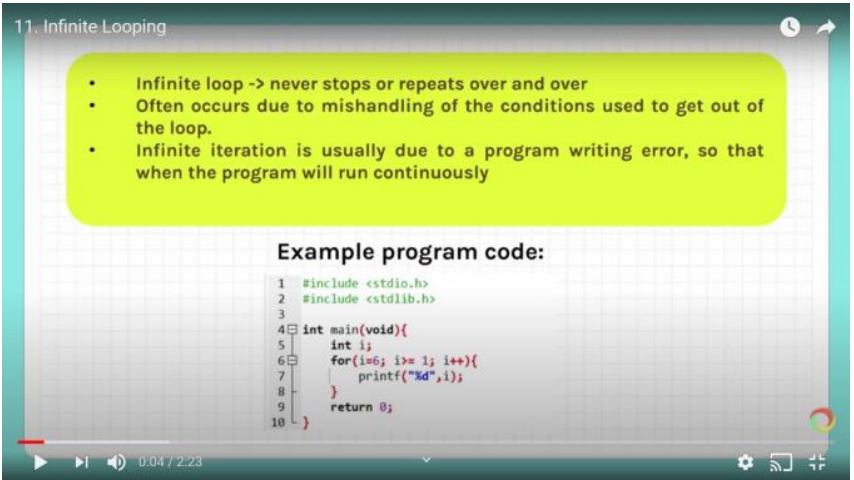

Figure 6 Contents of learning videos

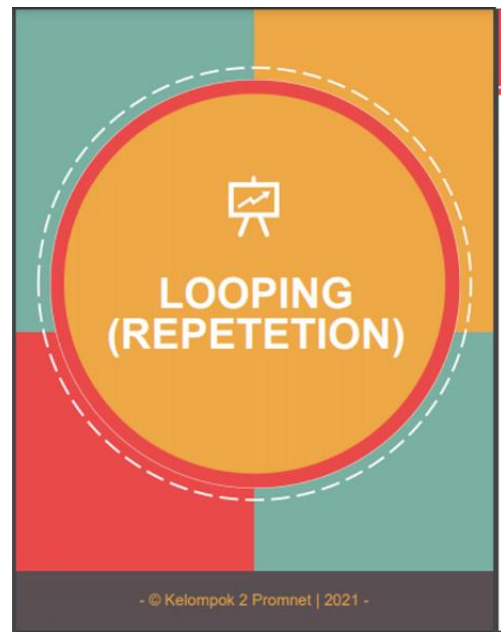

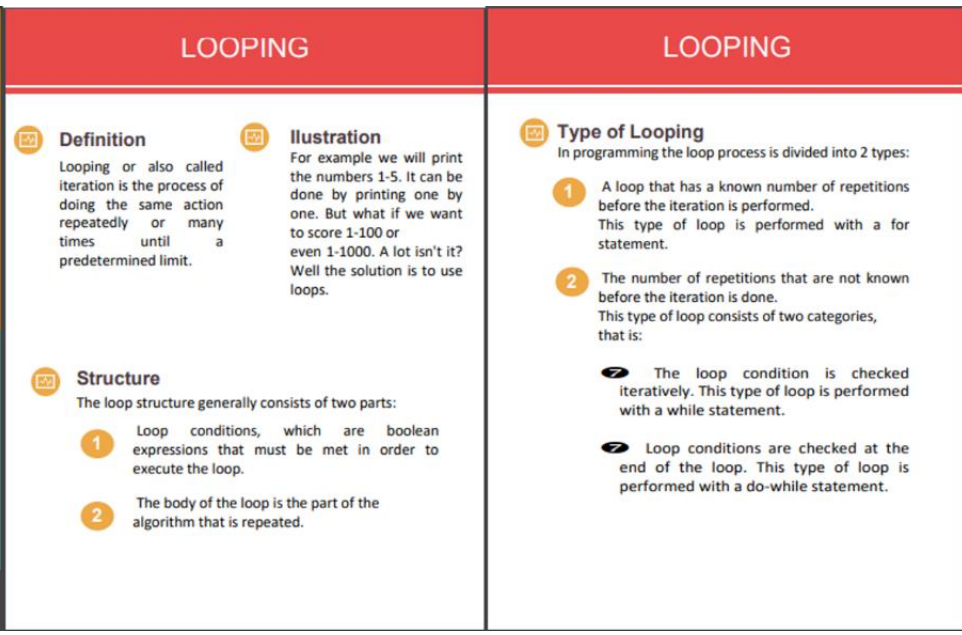

Figure 7 Material PDF module

\section{Tutorial Video}

Web Loopers has several interactive and visual features for presenting content, one of which is the use of video, as shown in Figure 5. Because many students propose presenting material through video, learning videos are used to present material. Moreover, video-based learning can increase students' interest and focus on learning (Nadeak \& Naibaho, 2020).

Figure 6 describes an example of the video content. Loopers web and Youtube are used to present learning videos. Learning videos are created based on material categories, resulting in 14 learning videos. Students can learn looping material by using the video feature on the Loopers web. Audio explanations of the material accompany the learning videos. Using audio-video in learning can encourage students' active participation in their hearing and vision, causing them to become more focused on their studies (Thézé et al., 2020).

\section{PDF Module}

Web Loopers includes a material module in PDF format. Students who enjoy reading will benefit from written material modules (Ling, 2018). Some students may not have enough time to watch learning videos, so reading this module is a good alternative. Furthermore, the PDF module makes it easier for students to see a summary of the material as study material when facing exams at school.

Figure 7 represents an example of a PDF module for loop material. The PDF format is designed to look like a study summary, with short, concise, and clear content. The number of PDF pages per material ranges from 3 to 8 pages. The appearance of the PDF is also enhanced by the use of different colors to help students understand the material.

Quiz

The quiz features available on the Loopers web are displayed in Figure 8. The quiz feature trains students and improves their understanding of each topic. There are 70 

Loopers
Home About Class Theory $~$ contact Score
R1
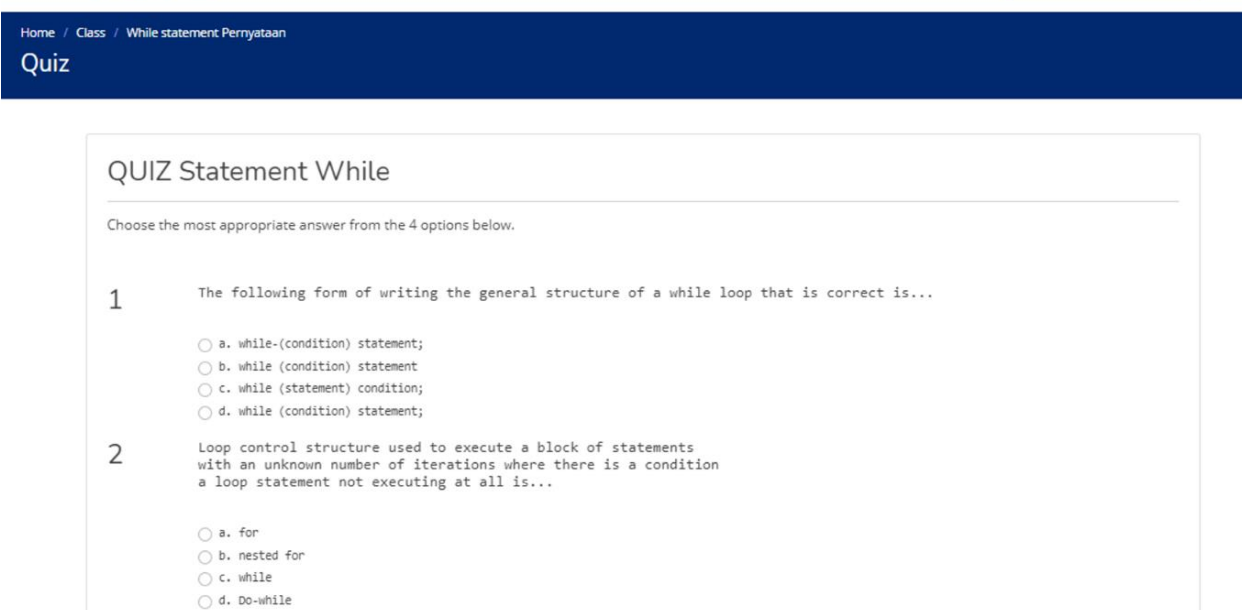

Figure 8 Quiz on Loopers web

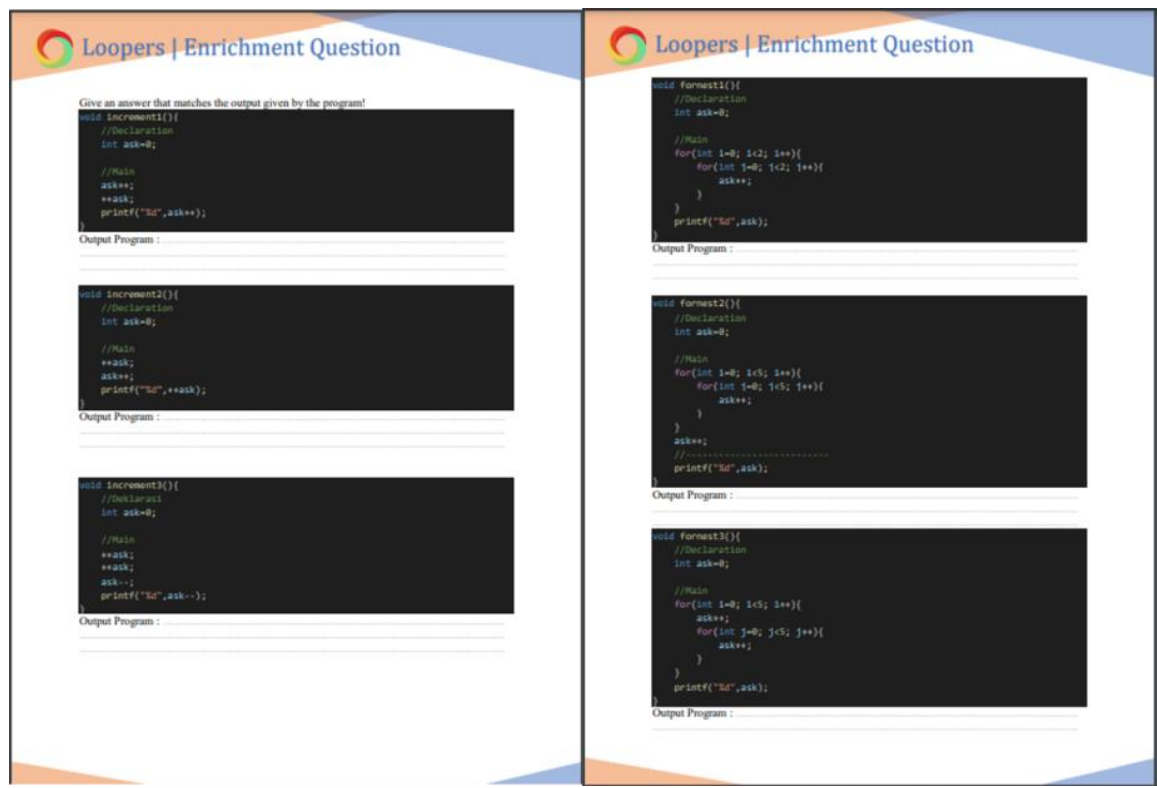

Figure 9 Enrichment Instruments

questions in each material, with two easy questions, two difficult questions, and one difficult question. The quiz is also intended to familiarize students with various types of questions. Students who want to practice additional sample questions can download the enrichment questions found on the class and material pages.

Quizzes can help students learn basic terms and concepts in various subjects. Furthermore, providing students with random quiz questions (demonstrating how concepts become more practical) can help them understand concepts and apply them to new contexts on subsequent tests (Nguyen \& McDaniel, 2015).

\section{Enrichment Instruments}

The enrichment instrument is a feature available on the Loopers web that allows students to explore additional learning materials related to their learning tasks. In order to achieve the best level of development and mastery of the material. Every student has direct access to and can download this feature. Enrichment services are provided to students who master the material faster by presenting them with more difficult learning challenges to help them achieve their maximum learning capacity (Brigandi, Weiner, Siegle, Gubbins, \& Little, 2018). Individual answers have been provided in each instrument to assist students in being more responsive and understanding each question criteria. Figure 9 represents the enrichment questions for all Looping materials on the Loopers website.

\section{Features of Score and Top Scoreboard}

Figure 10 represents the top score page on the Loopers website. The top score represents the acquisition of the highest score to the lowest score of each student who completed the quiz. Because their scores and names will be displayed on the top scoreboard, the top score is intended to foster students' competitive spirit and encourage them 
Quiz Top Scoreboard

\begin{tabular}{|c|c|c|c|c|c|}
\hline No & $\begin{array}{l}\text { Score } \\
\text { Quiz }\end{array}$ & Name & School Origin & Major & $\begin{array}{l}\text { Last Date of } \\
\text { Exam }\end{array}$ \\
\hline 1 & 1140 & R1 & $\begin{array}{l}\text { VOCATIONAL SCHOOL Pekerjaan Umum Negeri OF } \\
\text { WEST JAVA PROVINCE }\end{array}$ & $\begin{array}{l}\text { Computer and Network } \\
\text { Engineering }\end{array}$ & $\begin{array}{l}2021-06-08 \\
19: 48: 48\end{array}$ \\
\hline 2 & 1080 & R3 & $\begin{array}{l}\text { VOCATIONAL SCHOOL Pekerjaan Umum Negeri OF } \\
\text { WEST JAVA PROVINCE }\end{array}$ & $\begin{array}{l}\text { Computer and Network } \\
\text { Engineering }\end{array}$ & $\begin{array}{l}2021-06-07 \\
17: 20: 34\end{array}$ \\
\hline 3 & 1100 & R2 & $\begin{array}{l}\text { VOCATIONAL SCHOOL Pekerjaan Umum Negeri OF } \\
\text { WEST JAVA PROVINCE }\end{array}$ & $\begin{array}{l}\text { Computer and Network } \\
\text { Engineering }\end{array}$ & $\begin{array}{l}2021-06-07 \\
18: 29: 55\end{array}$ \\
\hline 4 & 1060 & R4 & $\begin{array}{l}\text { VOCATIONAL SCHOOL Pekerjaan Umum Negeri OF } \\
\text { WEST JAVA PROVINCE }\end{array}$ & $\begin{array}{l}\text { Computer and Network } \\
\text { Engineering }\end{array}$ & $\begin{array}{l}2021-06-09 \\
07: 33: 43\end{array}$ \\
\hline 5 & 1020 & R5 & $\begin{array}{l}\text { VOCATIONAL SCHOOL Pekerjaan Umum Negeri OF } \\
\text { WEST JAVA PROVINCE }\end{array}$ & $\begin{array}{l}\text { Computer and Network } \\
\text { Engineering }\end{array}$ & $\begin{array}{l}2021-06-10 \\
20: 37: 46\end{array}$ \\
\hline
\end{tabular}

Figure 10 Top Scoreboard

Loopers Home About Class Theory $\vee$ Contact Score

R1

Home / Class / Score list

Score list

R1's Score List

\begin{tabular}{|c|c|c|c|c|c|}
\hline No & Theory & Quiz Score & View Answer Key & Exam Date & Repeat Quiz \\
\hline 1 & While statement Pernyataan & 80 & see & 2021-06-18 06:10:17 & Try again \\
\hline 2 & Do While Statement & 80 & see & 2021-06-18 06:11:35 & Try again \\
\hline
\end{tabular}

Figure 11 Score history page

to compete and do their best work. The purpose of making a scoreboard is the same as the specific purpose of assessing learning outcomes which includes four things, that is a) knowing the success of the process education and teaching in schools, b) diagnosing learning difficulties, and c) motivating students' learning by knowing and understanding themselves and stimulating them to make improvement efforts (Dobson, 2008).

The view score page is visualized in Figure 11. The quiz scores completed by students are displayed on the score view page. The data is displayed in the form of quiz scores, name, school origin, major, and the last date of the exam and is sorted from highest to lowest score. Students can repeat quizzes that have been completed previously. Students who repeat the quizzes can correct the mistakes to get a maximum score. In addition, students can see the answers to each quiz question on the score page. Students were given answer keys and error information when filling out quizzes to re-learn material that they felt was difficult when working on quiz questions, which improved student learning outcomes (Sa'adah et al., 2018).

\section{Features with an Answer Key and Error Correction}

Figure 12 shows a feature in Web Loopers that allows students to view the quiz answer keys. We also added a feature that detects errors in Web Loopers quizzes answered by students. This feature allows web Loopers to interact with students more effectively. The system responds to students by displaying the quiz scores they have completed. The system provides answer keys and corrections for student-completed quizzes. Students can find out what errors they made when filling out the quiz. Following that, students can re-study the material with a less-than-ideal quiz score. This affects student learning outcomes (Sa'adah et al., 2018).

\subsection{Test Results of the Device Through Test}

Table 3 displays the results of the students' basic programming subjects. The majority of students have initial basic programming scores of more than 80 . This demonstrates that students' initial mastery of basic programming material is suitable (Anggraeni et al., 2020).

Table 4 compares students' pre-test and post-test scores after receiving the Loopers learning media. The students' average score increased after using the Loopers web, reaching 90 from 77.20 at the start. The standard deviation of the student's post-test is 3.73 , which is less than the standard deviation of the student's pre-test of 7.40, indicating that the difference between the sample values and the average is shrinking. The distribution of each 


\section{QUIZ Statement While}

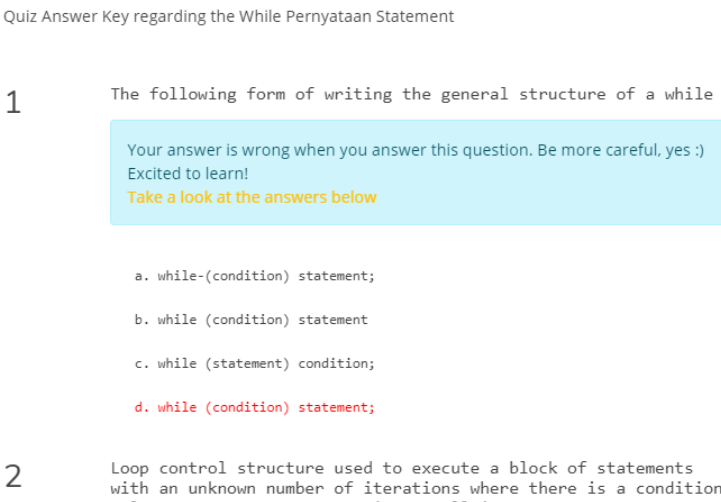

Figure 12 Error info and correct answer correction

Table 3 Student basic programming grades

\begin{tabular}{cc}
\hline Students & Score \\
\hline R1 & 80 \\
R2 & 64 \\
R3 & 80 \\
R4 & 80 \\
R5 & 81
\end{tabular}

student's knowledge of the looping material is improving and becoming more evenly distributed (the difference between) (Nissen, Talbot, Thompson, \& Van Dusen, 2018). This demonstrates that the Loopers web has proven an effective learning media.

\subsection{Descriptive Qualitative Data Analysis for Learning Outcomes}

This study analyzed the data by processing the information collected through the interview method, which is part of the descriptive qualitative research method. In addition, the results of the interviews were described in terms of predetermined problems. Based on Yusrizal, Safiah, \& Nurhaidah, (2017) research, we used nine points to determine the interview results by adjusting the questions asked to the respondents. The study mentioned seven factors to consider when determining the feasibility of learning media, some of which were the suitability of using learning media, the accuracy of learning media, and the ease of learning media. The following are the nine points based on the findings of an analysis of vocational school students' use of the Loopers web learning media to learn to loop.

1. The applicability of Loopers web learning media for learning to loop.

Based on the results of interviews with the five respondents about the suitability of using Loopers web
Table 4 Comparison of student's pre-test and post-test scores

\begin{tabular}{lll}
\hline Students & Pre-Test & Post-Test \\
\hline R1 & 80.00 & 95.00 \\
R2 & 64.00 & 90.00 \\
R3 & 80.00 & 91.67 \\
R4 & 80.00 & 88.33 \\
R5 & 81.00 & 85.00 \\
\hline Average & 77.20 & 90.00 \\
\hline Standard Deviation & 7.40 & 3.73 \\
\hline
\end{tabular}

learning media in learning to loop, R1 responded, "The learning media is very suitable, especially for students who are lazy to read. Because you can see the provided learning videos and the features are simple to use.".

$\mathrm{R} 2$ responded, "The learning media is very suitable to use because the features that are easy to understand make me not bored using it.".

R3 responded, "It is very suitable for web Loopers for students who want to learn looping, because the content of the explanation of the material is not complicated and easy to learn.".

R4 responded, "It seems appropriate to me. This looping material necessitates strong logic and numerous application examples to ensure that the concept is understood ".

R5 replied, "Web Loopers are very suitable to be used for learning looping material, it's just that I want additional material not only looping but all about basic programming."

Based on the results of interviews that have been conducted, it was found that Loopers, which is a webbased learning media with an emphasis on the use of 
various learning media, videos, texts, and practice questions, are suitable for use in looping learning. This is because learning using videos and other interactive media can increase students' understanding and interest (Anwar, Choirudin, Ningsih, Dewi, \& Maseleno, 2019).

2. The suitability of the looping material on the Loopers learning media for school-based looping learning.

Based on the findings of five interviews with respondents about the suitability of the looping material in Loopers learning media for looping learning at school, R1 responded, "The material presented at school and in Loopers is not much different. It's just that the difference in Loopers is much easier to understand than the explanation in school."

$\mathrm{R} 2$ responded, "The material presented at school and in Loopers is not much different, and if at school the teacher conveys at length, but students do not understand, then in Loopers the delivery is short but students can easily understand."

R3 responded, "Learning media on web Loopers is appropriate as material in general, made in a simple and easy to understand manner."

R4 responded, "Web Loopers are ideal for looping school lessons. It is just that the material from web Loopers is easier to understand than explanations at school, such as reading from printed books or listening to teacher explanations."

$\mathrm{R} 5$ responded, "The learning media is very easy to use for learning; you don't need to read a lot because the suitability of the material taught at school has been very clearly summarized in Loopers."

Loopers learning media is assessed according to what students learn at school. Students think that Loopers are very easy to use in learning because the material provided by Loopers is in accordance with what is taught at school. In addition, the Loopers material is made more concise to be easy to learn and understand. The material presented is also more structured with clear instructions. This agrees with the research conducted by Faust and Paulson (1998), where instructors can guide students toward a deeper understanding of the material presented.

3. Loopers learning media tools in the understanding of looping material.

Based on the results of interviews with the five respondents, R1 responded, "It is very helpful, when we run the quiz on this Loopers there will be an explanation and can be tried repeatedly."

R2 answered, "Very helpful and easier to understand".

R3 responded, "Very helpful, because I am too lazy to read, so seeing the learning video directly helps me understand the material. When there is a test or quiz, it is not difficult to find a collection of looping material. "

R4 responded, "Very helpful, because the looping material is very complete; there are learning modules, videos, and quiz questions that can be studied repeatedly."
R5 responded, "It is helpful, easy to understand, and provides students with easy access to the internet."

Based on the interviews, many students who used Loopers were helped and more easily understood the lessons, including videos, modules learning, and quizzes. They are helped to understand looping because the learning videos can be played repeatedly. Besides that, the quizzes can help them to increase their skills. This agrees with the research by Saeed, Yang, \& Sinnappan (2009) on the effect of using multiple and interesting learning media on web Loopers.

\section{The efficiency of video as a learning media}

Based on the results of interviews with the five respondents about the effectiveness of using video as a learning medium, R1 responded, "It is very effective, especially for online school conditions during the current pandemic." However, it is preferable if a teacher directly explains the material rather than simply providing learning videos."

R2 responded, "Effective because students can easily try it themselves right away."

R3 responded, "Very effective, because I am lazy to read, I can see videos that are easy to understand and can be put into practice right away."

R4 responded, "Very effective, because the explanation is quite clear and easy to understand."

R5 responded, "Effective, good because there is a video explanation. I'd rather have an explanation before doing/practicing coding."

Besides that, respondents stated that learning through video could be more enjoyable. This demonstrates the effectiveness of video as a learning medium (Yusuf, Zuhrawardi, \& Wardani, 2020). In addition, according to research by Arthur, Sekartaji, Arris Maulana, \& Dewi (2019) video media can increase student learning outcomes. 5. Availability of quizzes in Loopers learning media.

Based on the results of the Loopers quiz interview, R1 responded, "Good, the quiz is linked to the discussion module, and the questions are not strange, in my opinion." While R2 responded, "It is great that there is a quiz; you can try it right away; you do not have to wait for assignments anymore, so you understand right away." R3 responded, "It is excellent that the quiz can measure the ability to understand looping material." R4 responded, "Surprisingly, quizzes are available in Loopers. You can learn from the quiz if there is an exam." Finally, R5 responded, "It is good to have a quiz, but there are not many quiz questions because the knowledge is used for relearning."

In addition, the availability of score and top score features on the Loopers web that shows the result of the quiz can be used to determine the limits of students' knowledge about the Looping material and can also be used as material for student evaluation to be even better. As mentioned by R1, "With the availability of the score and 
top score features on the Loopers web, we can determine the limits of our abilities and evaluate them so that they can perform better in future quizzes or questions."

According to the following respondents, the top score feature can increase students' motivation and learning challenges and serve as a reward for themselves. For example, R3 stated, "It is interesting that I want to get a score of 100 continuously." While R4 stated, "It is more of a challenge for self-motivation if I can get a high score by studying," R5 also stated, "The score and top score feature is afraid to get a small score, but that way there is a reward for myself if I can and do not be lazy to learn basic programming."

By giving quizzes or practice questions on Web Loopers, students are helped to understand the material being studied. Students also become happy when they find challenges in the quizzes or practice questions provided. It was also approved by the journal Making a Game Out of It: Using Web-Based Competitive Quizzes for Quantitative Analysis Content Review, which stated that quizzes could help students learn and increase students' enjoyment of learning (Grinias, 2017).

6. Interest in learning looping material after making Loopers learning media.

Based on the results of interviews related to their interest in learning after using Loopers to study looping material, R1 answered, "I am happy to be interested in learning. Maybe we can add other material". While R2 replied, "I am very interested, very easy to understand, always free". R3 replied, "Very interested, because the explanation is short but easy to understand". R4 replied, "Interested, you don't need access to a lot of quotas, you can download learning modules". Finally, R5 replied, "Web Loopers are cool, so they are interested in learning looping by presenting material that doesn't bore us".

Based on the interviews from the five respondents after using the Loopers learning media, they were very interested in learning the looping material. Because the Loopers learning media is a freeware that is easily accessible by anyone. In addition, interactive learning media such as Loopers can make it easier for students to understand the material being taught with help, questions, videos, and learning modules. This agrees with Ramkissoon, Belle, \& Bhurosy (2020) that students prefer interactive online learning because it is adapted to their needs and interest in technology.

7. Web-based Learning Media increases learning motivation in Basic Programming subjects

Based on the results of interviews conducted to increase respondents' learning motivation in Basic Programming subjects through the use of web-based learning media (Vania, Setiawan, \& Wijaya, 2018), R1 replied, "It is quite motivated, but it is normal". In contrast to $\mathrm{R} 2$, he responded, "It increases when I am alone, it is just as easy to understand, and it is just as nice". R3 responded, "Yes, I am highly motivated, particularly during the pandemic. R4 answered, "Motivated to learn basic programming, especially looping". R5 answered, "yes, obviously motivated, online learning at Loopers can be done anywhere."

Loopers motivate students to learn repetition material. Loopers can be done anywhere, especially during the pandemic, many students have to study independently at home. The learning media can increase students' motivation to learn a lesson material that according to research by Winarto, Hardyanto, \& Sugianto (2019).

8. Loopers learning media include videos, content modules in $P D F$, and quizzes.

Based on the results of interviews regarding the availability of videos, material modules in the form of PDF, and quizzes, R1 replied, "That is enough", R2 responded, "Enough. R3 responded, "It is cool. There are free videos, learning modules, and quizzes, no need to pay like other learning websites." R4 answered, "Good and enough, but you can add more interesting learning video animation. R5 answered, "Learning videos can be played repeatedly. I can read the PDFs provided on the web at any time. So, when there is a test, the material provided on the web can be used for re-study."

Based on the interviews, the availability of videos, material modules in PDF form, and quizzes was measured. Many students believe that Loopers is quite clear in presenting material through videos, pdfs, and quizzes. It helps students to understand and evaluate themselves. In addition, the presentation of interesting material with delivery style through quizzes supports students to understand the material well (Higashinaka, Dohsaka, Amano, \& Isozaki, 2007).

\section{Web-based learning media's effectiveness and efficiency}

Based on the results of interviews related to the effectiveness and efficiency of using web-based learning media, R1 answered, "The website is good for the motivation of today's children who have difficulty learning, this is one of the most effective and efficient learning media, highly recommended because it can be accessed anywhere and anytime". Besides that, R2 answered "Effective and efficient because the learning media is easily accessible anywhere". R3 answered, "Very effective and efficient, through web-based learning, you can learn independently without time restrictions like in school". R4 replied, "Effective and efficient, especially now that the pandemic is all online, so you have to get used to online learning and access the learning web". R5 responded, "It is incredibly effective and efficient if you miss material at school, you can visit learning webs like Loopers learn anywhere and at any time."

Based on the interviews with the five respondents, they all agreed that web-based learning media was effective and efficient. Loopers web-based learning media can be helpful for students who have learning development 
problems. It also provides many conveniences for users, and it is recommended that they learn from Loopers. This is in accordance with the findings of Daniela, Kalnina, \& Strods (2017) and Astuti, Wihardi, \& Rochintaniawati (2020), who found that web-based learning media were feasible and effective.

The researcher concluded several characteristics of each respondent based on the five respondents' interviews. R1 is a student who prefers to learn through video media because he dislikes reading; the availability of videos can help R1 understand the concept of looping in basic programming subjects. Furthermore, R1 is a student who enjoys challenges, is pleased with the quiz, and is eager to re-learn the material when he receives unsatisfactory quiz results. Finally, R1 is very interested in learning looping through the Loopers website.

R2 is a student who enjoys practical concepts. R2 believes that the features available on the Loopers web are simple to understand. Web Loopers can be accessed at any time and from any location. When using web Loopers, R2 is interested and motivated to learn about looping.

$\mathrm{R} 3$ is a person who does not enjoy reading and prefers to learn through online videos. Loopers assists R3 in comprehending the looping material. R3 can use the practice questions to help him understand the looping material. R3 gains independence in learning looping with web Loopers.

R4 is a student who requires an application example to understand a learning material concept. Many examples from everyday life can be found in the Loopers web videos. As a result, R4 is very interested in learning how to use web Loopers, making looping material easier to understand.

R5 is a student who understands the material after reading a brief description. Loopers offers brief material in PDF format. When faced with an exam, R5 can use learning media in a PDF module to review the material. As a result, R5 enjoys using Web Loopers and is motivated to learn looping through them.

According to the findings of the interviews mentioned above, web Loopers can assist some students in their learning process. Web Loopers are popular among students and in high demand. Loopers can be used to prepare for school exams due to the compatibility of the looping material provided on the Loopers web with what students learn at school. The comprehensiveness of learning media used in web Loopers, such as creating experimental demonstration videos, descriptive modules in the form of PDFs, and practice questions (quiz and enrichment instruments), can boost students' learning motivation. Using more interactive, visual, and diverse learning media can boost students' motivation and learning performance (Saputri, Rukayah, \& Indriayu, 2018).

Many students offered ideas for developing Loopers learning media. As a result, we have been inspired to improve some of the features in web Loopers. In the future, we hope to add an animation feature to the material delivery process and some source code looping directly in the Loopers web. The addition of animation features was made in response to the requests of several students who participated in this study. The animation feature is thought to be more apparent in describing the material, allowing students to understand better the material presented and master learning outcomes more efficiently and effectively (Ismail, Othman, Amiruddin, \& Ariffin, 2017). In addition, the inclusion of source code in Loopers web allows students to directly practice looping coding by copying and pasting the provided code.

The Loopers learning media does not discuss the entire material on basic programming subjects. So that there is a need for further research and feature updates on Loopers based on student suggestions contained in the results and discussion. Loopers are expected to be a learning media that all groups can use. Loopers are not only used by students because Loopers make looping material easier to understand by using web media to present more interactive and visual material.

\section{CONCLUSION}

Based on the study, the making of learning media for looping materials on basic programming subjects using a web-based digital platform called Loopers is as follows: (1) Loopers is declared effective and suitable for use in productive learning processes involving repetition materials; (2) Students' responses to Loopers showed a strong desire to use Loopers because it increased their interest, motivation, and interest in the Loopers material. Loopers is learning media that discuss looping material clearly and complexly. Therefore, Loopers are expected to be a learning media used by all groups, not only students, because Loopers makes looping material easier to understand by using web media to present more interactive and visual material.

\section{ACKNOWLEDGMENT}

We would like to thank the five respondents from SMK Negeri PU Bandung who took in this research.

\section{REFERENCES}

Afriani, T., \& Agustin, R. R. (2019). The effect of guided inquiry laboratory activity with video embedded on students' understanding and motivation in learning light and optics. Journal of Science Learning, 2(4), 79-84.

Anggraeni, S., Nadhira, S. F., Azizah, N. N., Al Husaeni, D. F., Ragadhita, R., Hofifah, S. N., \& Nandiyanto, A. B. D. (2020). Teaching the effect of variations in types of flour on mechanical characteristics of chicken skin crackers through experimental demonstrations to senior high school students. Journal of Engineering Education Transformations, 34(2020), 102-107.

Anwar, M. S., Choirudin, C., Ningsih, E. F., Dewi, T., \& Maseleno, A. (2019). Developing an interactive mathematics multimedia learning based on ispring presenter in increasing students' interest in learning mathematics. Al-Jabar: Jurnal Pendidikan Matematika, 10(1), 135-150. 
Arthur, R., Sekartaji, G. T., Arris Maulana, L., \& Dewi, K. (2019) Pengembangan media video presentasi pada mata kuliah hidrologi di Universitas Negeri Jakarta [Development of video presentation media for hydrology courses at the State University of Jakarta]. Jurnal Teknologi Pendidikan, 7(02), 170-183.

Astuti, L., Wihardi, Y., \& Rochintaniawati, D. (2020). The development of web-based learning using interactive media for science learning on levers in human body topic. Journal of Science Learning, 3(2), 8998.

Attallah, B. (2017). Visualizing computer programming in a computerbased simulated environment. International Journal of Advanced Computer Science and Applications (IJACS A), 8(8), 369-378.

Brigandi, C. B., Weiner, J. M., Siegle, D., Gubbins, E. J., \& Little, C. A. (2018). Environmental perceptions of gifted secondary school students engaged in an evidence-based enrichment practice. Gifted Child Quarterly, 62(3), 289-305.

Brown, N. C. C., \& Wilson, G. (2018). Ten quick tips for teaching programming. PLoS Computational Biology, 14(4), e1006023.

Bryant, C. H., Muggleton, S. H., Page, C. D., \& Sternberg, M. J. (1999). Combining active learning with inductive logic programming to close the loop in machine learning. In Proc. AISB Symposium on AI and Scientific Creativity (pp. 221-234).

Cetin, I. (2020). Teaching loops concept through visualization construction. Informatics in Education-An International Journal, 19(4), 589-609.

Çoklar, A. N., \& Akçay, A. (2018). Evaluating programming self-efficacy in the context of inquiry skills and problem-solving skills: A perspective from tTeacher eEducation. World Journal on Educational Technology: Current Issues, 10(3), 153-164.

Daniela, L., Kalniņa, D., \& Strods, R. (2017). An overview on effectiveness of technology enhanced learning (TEL). International Journal of Knowledge Society Research (IJKSR), 8(1), 79-91.

Dobson, J. L. (2008). The use of formative online quizzes to enhance class preparation and scores on summative exams. Advances in Physiology Education, 32(4), 297-302.

Esteves, M., Fonseca, B., Morgado, L., \& Martins, P. (2011). Improving teaching and learning of computer programming through the use of the second life virtual world. British Journal of Educational Tecbnology, 42(4), 624-637.

Faust, J. L., \& Paulson, D. R. (1998). Active learning in the college classroom. Journal on Excellence in College Teaching, 9(2), 3-24.

Goncharov, S., Ospichev, S., Ponomaryov, D., \& Sviridenko, D. (2019). The expressiveness of looping terms in the semantic programming. ArXiv Preprint ArXiv:1912.02731.

Grinias, J. P. (2017). Making a game out of it: Using web-based competitive quizzes for quantitative analysis content review. Journal of Chemical Education, 94(9), 1363-1366.

Grover, S., Jackiw, N., \& Lundh, P. (2019). Concepts before coding: non-programming interactives to advance learning of introductory programming concepts in middle school. Computer Science Education, 29(2-3), 106-135.

Higashinaka, R., Dohsaka, K., Amano, S., \& Isozaki, H. (2007). Effects of quiz-style information presentation on user understanding. In Eighth Annual Conference of the International Speech Communication Association.

Ismail, M. E., Othman, H., Amiruddin, M. H., \& Ariffin, A. (2017). The use of animation video in teaching to enhance the imagination and visualization of student in engineering drawing. In IOP conference series: materials science and engineering (Vol. 203, No. 1, p. 012023). IOP Publishing.

Lin, M. H., \& Chen, H. G. (2017). A study of the effects of digital learning on learning motivation and learning outcome. Eurasia Journal of Mathematics, Science and Technology Education, 13(7), 35533564.

Ling, L. T. Y. (2018). Meaningful gamification and students' motivation: A strategy for scaffolding Reading Material. Online Learning, 22(2), $141-155$
Manik, E. (2020). Visual Basic 6.0 untuk. Media Pembelajaran Interaktif [Visual Basic 6.0 for Interactive Learning Media]. LPPM UHN Press.

Nadeak, B., \& Naibaho, L. (2020). Video-based learning on improving students learning output. PalArch's Journal of Archaeology of Egypt/Egyptology, 17(2), 44-54.

Nguyen, K., \& McDaniel, M. A. (2015). Using quizzing to assist student learning in the classroom: The good, the bad, and the ugly. Teaching of Psychology, 42(1), 87-92.

Nissen, J. M., Talbot, R. M., Thompson, A. N., \& Van Dusen, B. (2018). Comparison of normalized gain and Cohen's $\mathrm{d}$ for analyzing gains on concept inventories. Physical Review Physics Education Research, 14(1), 010115, 1-12.

Ramkissoon, P., Belle, L. J., \& Bhurosy, T. (2020). Perceptions and experiences of students on the use of interactive online learning technologies in Mauritius. International Journal of Evaluation and Research in Education, 9(4), 833-839.

Sa'adah, L., Nurkamto, J., \& Suparno, S. (2018). Oral corrective feedback: Exploring the relationship between teacher's strategy and students' willingness to communicate. Studies in English Language and Education, 5(2), 240-252.

Saeed, N., Yang, Y., \& Sinnappan, S. (2009). Emerging web technologies in higher education: A case of incorporating blogs, podcasts and social bookmarks in a web programming course based on student's learning styles and technology preferences. Journal of Educational Technology and \& Society, 12(4), 98-109.

Saputri, D. Y., Rukayah, R., \& Indriayu, M. (2018). Need assessment of interactive multimedia based on game in elementary school: A challenge into learning in $21^{\text {st }}$ century. International Journal of Educational Research Review, 3(3), 1-8.

Shouthiri, P., \& Thushika, N. (2018). A comparative analysis of looping structures: Comparison of 'While'Loop and 'Do-While'Loop in the $\mathrm{C}++$ ILanguage. Asian Journal of Research in Computer Science, 2(3), 15.

Tam, W. C. (1992). Teaching loop invariants to beginners by examples. Proceedings of the Twenty-Third SIGCSE Technical Symposium on Computer Science Education, 92-96.

Thézé, R., Gadiri, M. A., Albert, L., Provost, A., Giraud, A.-L., \& Mégevand, P. (2020). Animated virtual characters to explore audiovisual speech is controlled and naturalistic environments. Scientific Reports, 10(1), 1-12.

Vania, P. F., Setiawan, W., \& Wijaya, A. F. C. (2018). Edmodo as webbased learning to improve student's cognitive and motivation in learning thermal physics. Journal of Science Learning, 1(3), 110-115.

Winarto, A., Hardyanto, W., \& Sugianto, S. (2019). Telegram development in dokeos-based e-learning as a learning media to improve students' motivation in learning physics. Physics Communication, 3(2), 78-85.

Yusrizal, Y., Safiah, I., \& Nurhaidah, N. (2017). Kompetensi guru dalam memanfaatkan media pembelajaran berbasis teknologi informasi dan komunikasi (TIK) di SD negeri 16 Banda Aceh [Teacher competence in utilizing information and communication technology (ICT)-based learning media in SD Negeri 16 Banda Aceh]. Jurnal Ilmiah Mahasiswa Pendidikan Guru Sekolab Dasar, 2(2), 126-134.

Yusuf, M., Zuhrawardi, Z., \& Wardani, E. (2020). The effectiveness of animated video as learning media towards the perception of healthy snacks on elementary school students in Indonesia. The International Journal of Tropical Veterinary and Biomedical Research, 5(2), 1-6. 